\title{
Effect of Ag-Te doped Glass Frits on Interface Reaction and the Electrical Properties of Silicon Solar Cells
}

\author{
Feng Xiang, Wei-Ping Gan \\ School of Material Science and Engineering, Central South University, Changsha 410083, China. \\ *E-mail: 28977845@qq.com \\ doi: $10.20964 / 2018.06 .78$
}

Received: 12 October 2017 / Accepted: 11 April 2018 / Published: 10 May 2018

In this study, a new Ag-Te doped glass frits were used to prepare silver pastes in order to improve the electrical properties of silicon solar cells. A set of silver pastes was formulated to investigate the effect of the doping proportion on the electrical properties of the silicon solar cells. The silver paste with $5 \mathrm{wt} \%$ dopant increased the photovoltaic conversion efficiency of silicon solar cells by $0.199 \%$ compared to the increase achieved using the paste without the dopant. This effect could be attributed to the addition of dopant, which increased the size and number of Ag crystallites on the silicon wafer. The size and number of Ag crystallites were the major factors controlling the contact resistance between the silver electrode and the silicon wafer, and series resistance of solar cells. When the dopant proportion reached $10 \mathrm{wt} \%$ or $15 \mathrm{wt} \%$, the p-n junction broke due to the oversized Ag crystallites embedded in the p-n junction. Thus, the leakage current was observed, and this current degraded the electrical properties of the silicon solar cells. Therefore, the proper proportion of Ag-Te doped glass frits was necessary to obtain the optimal the silicon solar cells.

Keywords: Ag-Te doped glass frits; Ag crystallites; electrical properties; solar cells

\section{$\underline{\text { FULL TEXT }}$}

(C) 2018 The Authors. Published by ESG (www.electrochemsci.org). This article is an open access article distributed under the terms and conditions of the Creative Commons Attribution license (http://creativecommons.org/licenses/by/4.0/). 